\title{
Statyba
}

\section{THE QUANTITATIVE ASSESSEMENT OF THE LOCATION OF BUILDING PROJECTS IN A TERRITORY}

\section{R. Ginevičius}

To cite this article: R. Ginevičius (1995) THE QUANTITATIVE ASSESSEMENT OF THE LOCATION OF BUILDING PROJECTS IN A TERRITORY, Statyba, 1:4, 40-44, DOI: 10.1080/13921525.1995.10531532

To link to this article: https://doi.org/10.1080/13921525.1995.10531532

曲 Published online: 26 Jul 2012.

Submit your article to this journal

III Article views: 47 
ISSN 1392-1525. STATYBA - BUILDING CONSTRUCTION - CTPOИTE ЛЬCTBO, 1995, Nr. 4(4)

Statybos ekonomika ir vadyba

\section{STATYBOS OBJEKTU SKLAIDOS KIEKYBINIS IVERTINIMAS}

\section{R.Ginevičius}

\section{1. İvadas}

Statybos imonių (St) veiklos patirtis rodo, kad nèra universalaus organizacinès valdymo struktūros varianto arba formos, tinkančios visoms Sț. Kokia organizacinių taisyklių kombinacija yra tikslinga, priklauso nuo ju situacijos. Tą patvirtina ir empyriniai tyrimai, įrodantys, kad sèkmingai veikiančios įmonès turi visiškai skirtingas struktūras. Norint paaiškinti ši fenomeną, reikia empyriškai nagrinèti ịvairias situacijas ir žiūrèti, koks ryšys su jos atitinkančiomis organizacinių valdymo struktūnų (OVS) formomis.

Imonès situaciją apibūdina ịvairūs veiksniai. Dalis jų būdingi tik statybai. Vienas iš tokių statybos objektų sklaida. Jos poveikị SI struktūrai galima analizuoti tik ją išreiškus kiekybiškai.

\section{Statybos objektų sklaidos ịtaka jos organizacinei valdymo struktūrai}

Objektų sklaidos klausimui skirta daug mokslo tiriamuju darbų. Visuose juose siūloma, kaip tobulinti statybos paruošimą, planavimą ir pan., tačiau beveik niekur nenagrinejama itaka SI organizacinei valdymo struktūrai. Tuo tarpu manoma, kad tam turi būti skiriamas pastovus dèmesys, nes objektų teritorinis išsidèstymas yra vienas iš svarbių statybos įmonès valdymo bei gamybinès struktūrų faktorių [1].

Statybos koncentravimosi proceso analizė išryškino jo organizacinị-valdymo aspektą, t.y. poveikị OVS [2]. Kiekybiškai tai pasireiškia organizacijos dydžio kaip ịtakos faktoriaus, išplaukiančio iš vienos iš gamybos koncentravimosi formų, įtaka statybos įmonès specializavimuisi, svarbiausiai jos struktūrinei dimensijai.

Gamybos koncentravimasis yra sudètingas ir ịvairiapusiškas reiškinys, todèl greta organizacinio gali būti nagrinejjamas ir teritorinis aspektas bei jo, kaip ịtakos faktoriaus, poveikis organizaciniy valdymo formų efektyvumui [ 3]. 
Teritorinis statybos koncentravimasis - tai gamybos pajègumu išdèstymas tam tikrame rajone, teritorijoje. Taigi kiekvieną statybos įmonę galima apibūdinti jos organizacine-ūkine bei teritorine gamybos koncentracija ( žr. pav.).

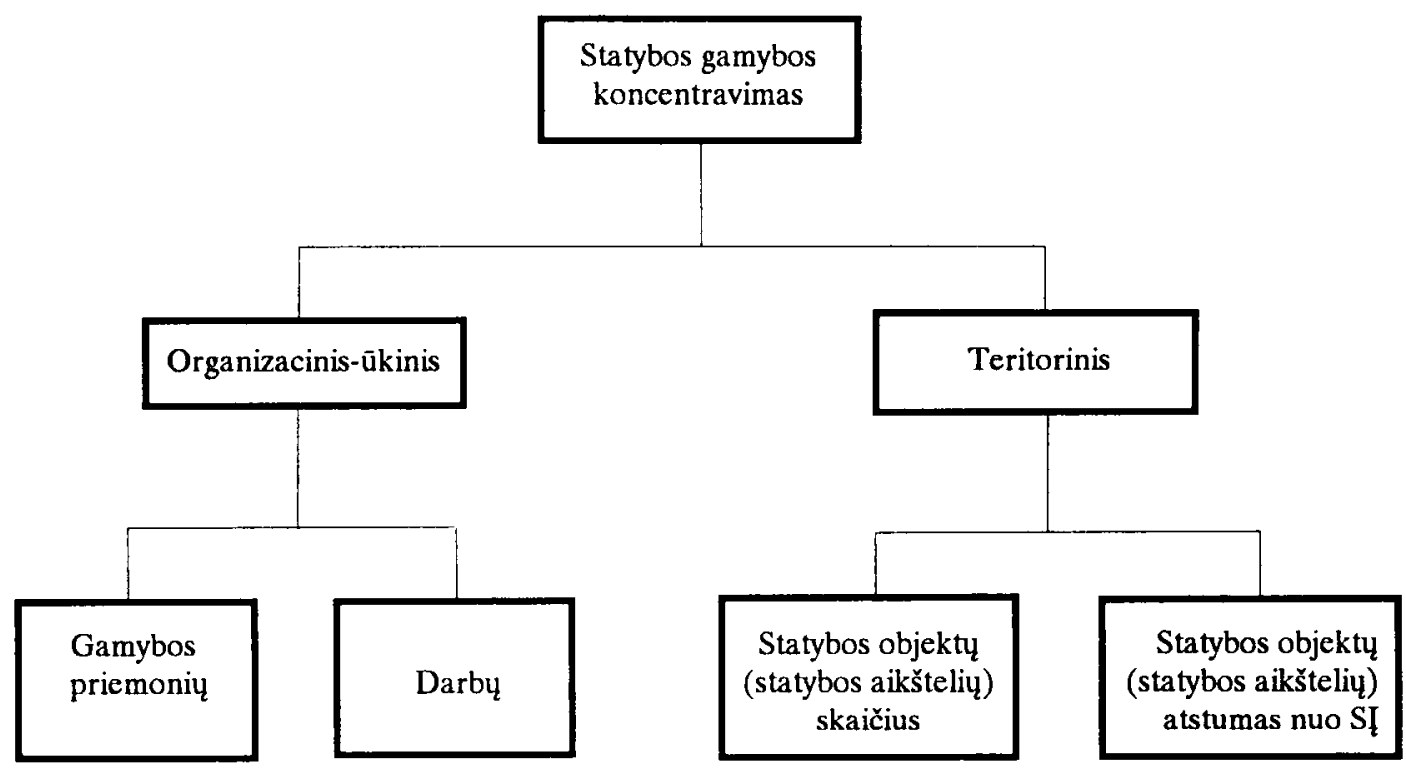

Statybos gamybos koncentravimosi formos

Organizacinio-ūkinio statybos koncentravimosi matavimo rodikliai parodo darbo, medžiaginiu ir techninių išteklių sutelkimo vienoje Sı laipsni. Šio proceso efektyvumas žymia dalimi priklauso nuo to, kokioje teritorijoje tai atliekama ir kiek objektų vienu metu statoma.

\section{Statybos objektų teritorinio išsidėstymo kiekybinis ịvertinimas}

Nèra vieningos nuomonès dél statybos objektų sklaidos kiekybinio įvertinimo, kadangi šiam palyginti paprastam klausimui skirta daug darbų. Apie tai taip pat liudija didelé siūlomų rodiklių ivairovė [1]:

- statybos ir montavimo darbų koncentravimo laipsnis;

- vidutinis nuotolis nuo SỊ iki statybos objektų;

- vidutinè metiné darbų apimtis, tenkanti vienai statybos aikštelei;

- statybos objektų vidutiné sąmatinè verté;

- darbu apimtis, tenkanti aptarnaujamos teritorijos ploto vienetui;

- objektụ skaičius;

- statybos aikštelių skaičius ir pan. 
Labiausiai buvo nagrinéjamas vidutinio nuotolio nuo SI iki statybos objekto ar aikštelès rodiklis, kuris nustatomas taip $[4,5,6,8]$ :

$$
R v s=\frac{\sum_{i=1}^{n} q_{i} r_{i}}{\sum_{i=1}^{n} q_{i}}
$$

čia $R_{v S}$ - vidutinis svertinis spindulys, $\mathrm{km} ; q_{i}$ - statybos darbu apimtis $i$-je statybos aikštelèje; $r_{i}$ - atstumas SI iki $i$-s statybos aikštelès; $n$ - statybos aikštelių skaičius.

Kiti autoriai mano, kad dydis $R_{v S}$ netobulas, nes nepakankamai ivertina statomu objekty skaičių bei darbų apimtis vienoje statybos aikštelèje. Jie pasiūlè keletą patikslintų dydžio $R$ skaičiavimo būdų. Pavyzdžiui [7], $R$ siūloma skaičiuoti taip:

$$
R=\frac{\sum_{i=1}^{n} \alpha k_{i} \beta l_{i}}{K} m,
$$

čia $\quad R$ - SI statomų objektų sklaidos koeficientas; $k_{i}$ - metinès darbų apimtys $i$-me statybos objekte; $l_{i}$ - atstumas nuo SI arba jos gamybinès bazès iki $i$-jo statybos objekto; $n$ - statomy objekty skaičius; $\quad K=\sum_{i=1}^{n} k_{i}-\mathrm{SII} \mathrm{metinè} \mathrm{darbų} \mathrm{apimtis;} \alpha, \beta, \gamma$ - pastovūs dydžiai, charakterizuojantys faktorių $k, l$ ir $n$ poveikị išlaidų, išreikštų procentais nuo darbų savikainos, pasikeitimui.

Manydami, kad (2 ) formulè netobula metodiškai, kiti autoriai siūlo savo dydžio $R$ skaičiavimo išraišką [ 8]:

$$
R=n \frac{\alpha \sum_{i=1}^{n} q_{i} \frac{\left(r_{i}+1\right) \beta}{q_{i} \gamma}}{\sum_{i=1}^{n} q_{i}}
$$

čia $n$-statybos aikštelių skaičius; $q_{i}$ - darbų apimtys $i$-je statybos aikštelèje; $r_{i}$ - atstumas nuo SI bazès iki $i$-s statybos aikštelès; $\alpha, \beta, \gamma$-koeficientai.

Prie supaprastintų statybos objektų sklaidos skaičiavimo būdų priskiriama: darbų apimtis, tenkanti vienai statybos aikštelei, arba atvirkščias dydis - statybos aikštelių skaičius, tenkantis tam tikram darbų, išreikštų pinigais, apimties vienetui; vidutinis atstumas tarp statybos aikštelių; objektų, statybos aikšstelių skaičius; darbų apimtis, tenkanti aptarnaujamos teritorijos ploto vienetui, ir pan. $[1,5]$. 
Statybos įmonès statomų objektų sklaidos kiekybinio įvertinimo būdų analizè leidžia atsakyti ị klausimą, kodèl jų yra tiek daug ir kodèl šiuo klausimu nèra vieningos nuomonès. Beveik kiekvienas iš autorių matè skirtingą siūlomo rodiklio pritaikymo tikslą. Pavyzdžiui, [1] darbe buvo siekiama nustatyti, kaip statybos gamybos sklaida veikia SI valdymo aparato dydį; kiti autoriai mané, kad jų siūlomus kriterijus galima panaudoti parenkant mechanizavimo, transporto priemones, gamybinių ir aptarnaujančių pastatų dydị ir tipą, darbų vykdymo, statybos organizavimo būdus ir pan. [7], dar kiti - darbininku, reikalingu statybos organizaciniamtechnologiniam paruošimui, skaičiu ir sudetị, sudarant statybos organizavimo projektus, darbo laiko išteklių einamuosius ir perspektyvinius planus [9] ir t.t. Todèl SI statomų objektų sklaidą aiškinant, kaip situacijos veiksni, ir ieškant jos reprezentacinès išraiškos, ją reikia pateikti taip, kad išryškẻtų poveikis organizacinei valdymo struktūrai. Nagrinèjant šiuo požiūriu siūlomus rodiklius, pirmenybę reikètų suteikti tiems, kurie labiau atspindi pirminių Sİ padalinių (grandžių, brigadų, barų) atsiradimo sąlygas. Tuo remiantis galima pasiūlyti tokius rodiklius: 1) statybos aikštelių (objektų) skaičius, 2) darbų apimtis, tenkanti aptarnaujamos teritorijos ploto vienetui. Kuris iš jų labiausiai tinka, parodys empyrinè analizè.

\section{Išvados}

1. Objektų sklaidą siūloma ịvertinti daugeliu rodiklių, atspindinčių jos poveikị ịvairioms statybos proceso pusèms. Tuo tarpu beveik nèra tyrimų, skirtu statybos teritorinio koncentravimosi įtakai Sl̨ organizacinei valdymo struktūrai nagrinèti.

2. Statybos objektų sklaidą aiškinant kaip Sİ situacijos veiksnį, ji reikia pateikti tokia forma, kad būtu atspindètas poveikis įmonès OVS.

3. Šiuo požiūriu galimi tokie objektų sklaidos rodikliai: a) statybos aikštelių (objektų) skaičius; b) darbų apimtis, tenkanti aptarnaujamos teritorijos ploto vienetui.

\section{Literatūra}

1. А.К.Шрейбер, А.Л.Талалай, Л.Г.Палян. Влияние рассредоточенюости производства на параметры управляющей системы // Известия высших учебных заведений СССР. Строительство и архитектура, 3, 1975, с. 89-96.

2. Р.М.Гинявичюс. Методолопия определения размера строительно-монтажной организацин. Вильнюс, 1988. 18 с. Деп. в ЈитНИИНТИ.

3. А.А.Климов. Экономическое обоснование вариантов структуры управления строителыным производством. М.: Стройиздат, $1985.128 \mathrm{c}$.

4. Б.С.Босв. Опыт совершенствования организации и управления строителыной индустрией. М.: Стройиздат, 1987. $144 \mathrm{c}$. 
5. Н.П. Большаков и др. Эффективность специализации. Сыктывкар: Коми книжное издательство, 1983. $120 \mathrm{c}$.

6. Ю.А.Ткаченко. Методические основы определения оптимальных размеров строительных организаций (на примере Главмосстроя). М., 1981. 195 с.

7. Е.Кротков. Метод оценки рассредоточенности строительства // Экономика строительства, 5, 1967, с. 61-64.

8. Л.Петров, А.Талалай, С.Смоляк. Себестоимость работ и рассредоточенность // Экономика строительства, 6, 1969, с. 49-52.

9. Ю.Э.Ладьянов. Объективный метод оценки фактора рассредоточенности // Совершенствование организации и управления строительством. М.: Стройиздат, 1974. $96 \mathrm{c}$.

\section{THE QUANTITATIVE ASSESSEMENT OF THE LOCATION OF BUILDING PROJECTS IN A TERRITORY}

\section{R.Ginevičius}

S u m m a r y

In many research works concerning the dispersion of building projects the influence of this dispersion on organizational structures of building enterprise management has not been almost touched upon. However, the territorial concentration of production is one of the most important structural factor. The quantitative evaluative analysis allows us to auswer the question: why is there no common oppinion on this problem? The main reason is that the fields and aims of applying this factor by various researchers are different.

When the dispersion is considered as a structural factor, it's index must reflect the influence of dispersion on the organizational structure of the enterprise management. The index may be represented by the number of building sitez or the amount of work per territorial unit. 